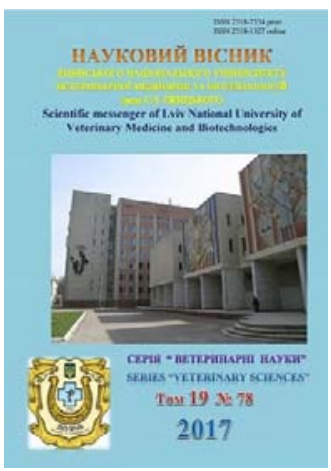

Науковий вісник Львівського національного університету ветеринарної медицини та біотехнологій імені С.З. Гжицького

Scientific Messenger of Lviv National University of Veterinary Medicine and Biotechnologies

doi:10.15421/nvlvet7811

ISSN 2518-7554 print

ISSN 2518-1327 online

$\underline{\text { http://nvlvet.com.ua/ }}$

УДК 338.43:006.83:637.1

\title{
Алгоритм імплементації належної практики молочного фермерства 3 метою отримання безпечного та якісного молока-сировини
}

\author{
Л.А. Кондрасій, О.М. Якубчак, Л.В. Шевченко \\ l.kondrasiy@nubip.edu.ua \\ Національний університет біоресурсів і природокористування України, \\ вул. Героїв Оборони, 15, м. Київ, 03041, Украӥна
}

\begin{abstract}
Нині в Украӥні відсутній контроль санітарії та гігієни отримання молока-сировини на фермі, щзо пов'язано з дією розпорядження прем'єр-міністра Украӥни «Про визнання такими, щэо втратили чинність, та такими, що не застосовуються на території України, актів санітарного законодавства» № 94-р редакція від 20.01.2016. Оцінка щзодо окремих показників безпечності та якості молока здійснюється лише під час надходження його на переробку. На підставі аналізу сучасного стану виробництва молока-сировини в Украӥні розроблено алгоритм імплементації належної практики молочного фермерства в умовах молочних ферм Украӥни. Розроблений нами алгоритм базується на принципах належної практики молочного фермерства та належної фермерської практики. Імплементація алгоритму надає можливість забезпечити та проаналізувати отримання безпечного та якісного молока-сировини на фермах України. Алгоритм імплементаиії належної практики молочного фермерства в умовах ферм України складає створення робочої групи, розроблення 12-ти програм (які забезпечені 71-ю інструкцісю) та обов'язкову наявність прифермської лабораторії.

На підставі даних досліджень технічного забезпечення та практик отримання молока на фермах України розроблено два блоки програм забезпечення належної практики молочного фермерства: блок програм забезпечення благополуччя корів та блок програм отримання безпечного та якісного молока-сировини. До першого блоку увійтли програми: належні параметри мікроклімату корівника, належна гігієна та технічний стан корівника і території ферми, гігієна кормів та води, належний ветеринарний менеджмент, вирощування телят і гігієна та охорона праці осіб, зайнятих у догляді корів. До другого - підготовка корів до доӥння, належна прочедура доӥння, заходи після доӥння, технічна справність молочного обладнання, належний санітарно-гігієнічний стан молочного інвентарю й обладнання та мікроклімат молочного блоку, гігієна та охорона прачі осіб, зайнятих у молочному блочі ферми.
\end{abstract}

Ключові слова: молоко-сировина, безпечність, якість, належна практика молочного фермерства.

\section{Алгоритм имплементации надлежащей практики молочного фермерства с целью получения безопасного и качественного молока-сырья}

\author{
Л.А. Кондрасий, А.Н. Якубчак, Л.В. Шевченко \\ 1.kondrasiy@nubip.edu.ua \\ Национальный университет биоресурсов и природопользования Украины, \\ ул. Героев Обороны 15, г. Киев, 03041, Украина
}

\begin{abstract}
На сегодня в Украине отсутствует контроль санитарии и гигиены получения молока-сырья на ферме, что связано с действием распоряжения премьер-министра Украины «О признании актов санитарного законодательства такими, что потеряли силу и не применяются на территории Украины» № 94-р от 20.01.2016. Оченка по отдельным показателям безопасности и качества молока осуществляется только при поступлении молока на переработку. На основании анализа современного состояния производства молока-сырья в Украине разработан алгоритм имплементации надлежащей практики молочного фермерства в условиях молочных ферм Украины. Разработанный нами алгоритм базируется на принципах
\end{abstract}

\section{Citation:}

Kondrasii, L.A., Iakubchak, O.M., Shevchenko, L.V. (2017). An algorithm for good dairy farming practices implementation in order to obtain safety and quality raw milk. Scientific Messenger LNUVMB, 19(78), 53-57. 
надлежащей практики молочного фермерства и надлежашей фермерской практики развитых стран мира. Имплементация алгоритма позволит обеспечить и проанализировать получение безопасного и качественного молока-сырья на фермах Украины. Алгоритм имплементации надлежащей практики молочного фермерства в условиях ферм Украины составляет создание рабочей группь, разработку 12-ти программ (которые обеспечень 71-й инструкцией) и наличие прифермской лаборатории.

На основании данных исследований технического обеспечения и практик получения молока на фермах Украины разработано два блока программ обеспечения надлежащей практики молочного фермерства: блок программ обеспечения благополучия коров и блок программ получения безопасного и качественного молока-сырья. В первый блок вошли программы: надлежащие параметры микроклимата коровника, надлежащая гигиена и техническое состояние коровника и территории фермы, гигиена кормов и воды, надлежащцй ветеринарный менеджмент, выращивание телят, а также гигиена и охрана труда лич, занятых в уходе за стадом. Ко второму блоку вошли программы: подготовка коров к доению, надлежащуая процедура доения, мероприятия после доения, техническая исправность молочного оборудования, надлежащее санитарно-гигиеническое состояние молочного инвентаря и оборудования, микроклимат молочного блока, а также гигиена и охрана труда лии, занятых в молочном блоке фермы.

Ключевые слова: молоко-сырье, безопасность, качество, надлежащая практика молочного фермерства.

\title{
An algorithm for good dairy farming practices implementation in order to obtain safety and quality raw milk
}

\author{
L.A. Kondrasii, O.M. Iakubchak, L.V. Shevchenko \\ 1.kondrasiy@nubip.edu.ua
}

\author{
National University of Life and Environmental Sciences of Ukraine, \\ Heroiv Oborony Str., 15, Kyiv 03041, Ukraine
}

Currently, Ukraine has not control of sanitation and hygiene of obtaining raw milk on the farm. This is connected of the Order of the Prime Minister of Ukraine dated January 20, 2016, No. 94-p «On the recognition of invalid acts, and those that are not applicable in Ukraine, regulations of sanitary legislation» The assessment of some safety and quality indicators of milk is carried out only when milk is received for processing. An algorithm for the implementation of good dairy farming practices in Ukrainian farms has been developed, that give consideration the analysis of the current practices of raw milk production in Ukraine. The algorithm is based on the principles of good dairy farming practices and good farming practices for animal production food safety. The implementation of the algorithm will give an opportunity to provide and analyze of raw milk safety and quality parameters on Ukrainian farms. An algorithm of good dairy farming practices implementation on Ukraine farms take into account the creation of a working group, the development of 12 programs (which are provided with the 71 st instruction) and the establish a farmstead laboratory.

Give consideration research data about technical support and milk production practices at Ukrainian farms, we have been developed two blocks of programs to implement good dairy farming practices. a block of cow welfare programs and a block of programs for obtaining safe and high-quality milk-raw materials. The first-A block of programs for ensuring of cows welfare, includes programs: good stable climate, dairy barn and farm territory hygiene and technical condition, feed and water hygiene, good veterinary management, calves management, and occupational health of cow's carers. The second - A block of programs for ensuring safety and quality raw milk, includes programs: preparation of cows for milking, good milking practice, post-milking measures, control of support for technical serviceability of dairy equipment, good sanitary and hygienic status of dairy equipment and milking room, and the hygiene and occupational health of persons employed in the milking of the farm.

Key words: raw milk, safety, quality, good dairy farming practice

\section{Вступ}

Нині оцінка санітарії та гігієни виробництва молока-сировини в Україні контролюється під час надходження молока на переробні потужності за окремими показниками безпечності та якості згідно з ДСТУ 3662-97. При цьому санітарія та гігієна виробництва молока на фермі не контролюються, що пов'язано 3 дією розпорядження прем'єр-міністра України «Про визнання такими, що втратили чинність, та такими, що не застосовуються на території України, актів санітарного законодавства» № 94-р, редакція від 20.01.2016. Застосовувані практики отримання молока-сировини зазвичай зумовлені рівнем технічного забезпечення, а відтак досить різняться. Внаслідок цього якісний склад отриманого молока непередбачуваний, що ускладнює планування технологічних процесів його переробки та гарантування очікуваних споживачами сенсорних властивостей (Dykun, 2017). Про актуальність впровадження нале- жних практик отримання молока-сировини на фермах говорять як науковці, так і експерти галузі. Належна санітарія та гігієна отримання молока на фермі гарантує безпечність та якість молочних продуктів (Dufour et al., 2011; Nita, 2016; Tsikunova, 2016). Отже, метою нашої роботи було розробити алгоритм імплементації належної практики молочного фермерства в Україні.

\section{Матеріал і методи досліджень}

Для досягнення мети досліджено технічне забезпечення та практики отримання молока у НДГ ВП НУБіП України та окремих приватних фермах, а також оцінено якісні показники отримуваного ними молока-сировини. Крім того, проаналізовано вітчизняні та зарубіжні літературні джерела щодо забезпечення належної практики молочного фермерства (Guide To Good..., 2010; Iakubchak, 2010; Guide to good..., 2011). 


\section{Результати та їх обговорення}

Дослідженням технічного забезпечення та практик отримання молока у НДГ ВП НУБіП України та окремих приватних фермах встановлено найбільш поширені невідповідності: нехтування параметрами мікроклімату корівників; один працівник ферми може бути задіяний у різних напрямках діяльності ферми в один часовий проміжок; працівники опановують програми доїння та користування доїльним апаратом 3 досвіду попередників; окремі програми доїння, очищення молочного обладнання та гігієни осіб, зайнятих у доїнні, спрощені, чим здатні зумовити ризики появи у молоці-сировині небезпечних чинників; відсутня програма періодичної перевірки та корекцій технічної справності доїльних апаратів. Показники якості молока-сировини від досліджуваних ферм нестабільні та іноді відповідають нижчим гатункам згідно з ДСТУ 3662-97. Отже за результатами досліджень сформовано алгоритм імплементації належної практики молочного фермерства в умовах ферм України, що складає створення робочої групи, розроблення 12-ти про- грам (які забезпечені 71-ю інструкцією) та обов'язкову наявність прифермської лабораторії.

Запровадження належної практики молочного фермерства повинно розпочатися зі створення робочої групи, а також впровадження програм безпечності; обговорення та документального оформлення концепції розвитку; визначення критичних етапів технологічного процесу отримання молока (критичні етапи поділяють на термінові, менш термінові та на перспективні); складання детального плану вирішення невідповідностей із зазначенням відповідальних працівників та термінів виконання корекцій чи коригувальних дій. Варто зазначити, що фахівці робочої групи повинні усвідомити, що результат приходить не відразу, необхідне застосування принципу «step by step». Фахівці робочої групи повинні проводити постійний пошук заходів досягнення мети за науковообгрунтованим принципом із максимальним економічним ефектом. Усі працівники ферми зобов'язані проходити періодичне навчання щодо принципів виконання належних практик на фермі.

Програми забезпечення належної практики молочного фермерства поділено на два блоки (табл. 1).

Табличя 1

Програми належної практики молочного фермерства щодо отримання безпечного та якісного молокасировини на фермі

\begin{tabular}{|l|l|c|}
\hline \multicolumn{1}{|c|}{ Блок програм забезпечення благополуччя корів } & Інструкції \\
\hline 1.1. & Належні параметри мікроклімату корівника & 3 \\
\hline 1.2. & Належна гігієна та технічний стан корівника та території ферми & 10 \\
\hline 1.3. & Гігієна кормів і води & 5 \\
\hline 1.4. & Належний ветеринарний менеджмент & 15 \\
\hline 1.5. & Вирощування телят & 22 \\
\hline 1.6. & Гігієна та охорона праці осіб, зайнятих у догляді корів & 3 \\
\hline \multicolumn{1}{|c|}{ Блок програм отримання безпечного та якісного молока } \\
\hline 2.1. & Організація роботи щодо корів & 2 \\
\hline 2.1 .1$. & Підготовка корів до доїння & 1 \\
\hline 2.1 .2$. & Належна процедура доїння & 1 \\
\hline 2.1 .3$. & Заходи після доїння & \\
\hline 2.2. & Організація роботи щодо молочного блоку ферми & 3 \\
\hline 2.2 .1 & Технічна справність молочного обладнання & 4 \\
\hline 2.2 .2$. & $\begin{array}{l}\text { Належний санітарно-гігієнічний стан молочного інвентарю, обладнання та мікроклімат } \\
\text { молочного блоку }\end{array}$ & 2 \\
\hline 2.2 .3$. & Гігієна та охорона праці осіб, зайнятих у молочному блоці ферми & 2 \\
\hline
\end{tabular}

Перший блок включає програми, що забезпечують благополуччя корів на молочній фермі, другий отримання безпечного та якісного молока-сировини. Кожна процедура забезпечується виконанням інструкцій. Так, доцільно розробити інструкції задля забезпечення таких вимог.

1.1. Належні параметри мікроклімату корівника 3 інструкції (1. Підтримання належного температурно-вологісного режиму. 2. Вимоги до вмісту у повітрі $\mathrm{CO}_{2}, \mathrm{HN}_{3}, \mathrm{H}_{2} \mathrm{~S}, \mathrm{PlO}_{2}, \mathrm{SO}_{2}, \mathrm{CO}$, наявності твердих часток вуглецю (сажа від використання дизельних двигунів на обслуговуючій техніці), радіоактивність. 3. Вимоги до належної швидкості руху повітря та освітлення у корівнику).

1.2. Належна гігієна та технічний стан корівника та території ферми - 10 інструкцій. (1. Підтримання цілісності стін, даху, вікон, підлоги та воріт корівника. 2. Проведення дезінфекції корівника. 3. Проведення дератизації корівника. 4. Проведення дезінсекції корівника. 5. Догляд за чистотою території ферми. 6. Забезпечення чистоти та міцності конструкцій корівника, огорож їх з'єднань. 7. Забезпечення належного очищення та зберігання засобів із догляду за коровами. 8. Очистка стічних вод. 9. Видалення гною із корівника. 10. Знезараження гною).

1.3. Гігієна кормів і води - 5 інструкцій. (1. Заготівля та/або закупівля кормів (за видами). 2. Належне зберігання кормів (за видами). 3. Складання раціонів. 4. Підготовка та роздача кормів. 5. Гігієна води).

1.4. Належний ветеринарний менеджмент 15 інструкцій (1. Щеплення. 2. Протипаразитарні обробки. 3. Огляд та лікування ратиць. 4. Діагностика субклінічних форм маститу та схема лікування корів, хворих на мастит. 5. Схеми поводження та лікування за інфекційних хвороб. 6. Схеми поводження та лікування за паразитарних хвороб. 7. Схеми поводження та лікування за хірургічних хвороб. 8. Схеми поводження та лікування за хвороб внутрішніх органів. 
9. Проведення планових оперативних втручань, їх схеми. 10. Поводження з молоком від хворих корів та у лікуванні яких застосовуються антибіотики, гормони. 11. Поводження з коровами у різних фізіологічних станах (початок/кінець тільності, роди, післяродовий період). 12. Роди та схеми допомоги за умов патології родів корів. 13. Штучне осіменіння та контроль запліднення. 14. Перевезення корів. 15. Здавання на забій. 16. Менеджмент новоприбулих (карантин, обробки, присвоєння інвентарного номера).

1.5. Вирощування телят - 22 інструкції (1. Підтримання належного температурно-вологісного режиму. 2. Щодо вмісту у повітрі $\mathrm{CO}_{2}, \mathrm{HN}_{3}, \mathrm{H}_{2} \mathrm{~S}, \mathrm{PlO}_{2}$, $\mathrm{SO}_{2}, \mathrm{CO}$, наявності твердих часток вуглецю (сажа від використання дизельних двигунів на обслуговуючій техніці), радіоактивність. 3. Щодо належної швидкості руху повітря та освітлення у телятнику. 4. Щодо підтримання цілісності стін, даху, вікон, підлоги та воріт телятника. 5. Проведення дезінфекції телятника. 6. Проведення дератизації телятника. 7. Проведення дезінсекції телятника. 8. Забезпечення чистоти та міцності конструкцій телятника. 9. Забезпечення належного очищення та зберігання засобів із догляду за телятами. 10. Складання раціонів. 11. Підготовка та роздача кормів. 12. Щеплення. 13. Протипаразитарні обробоки. 14. Схеми поводження та лікування за інфекційних хвороб. 15. Схеми поводження та лікування за паразитарних хвороб. 16. Схеми поводження та лікування за хірургічних хвороб. 17. Схеми поводження та лікування за хвороб внутрішніх органів. 18. Проведення планових оперативних втручань їх схеми. 19. Перевезення телят. 20. Здавання на забій. 21. Менеджмент новоприбулих (карантин, обробки). 22. Присвоєння інвентарного номера).

1.6. Гігієна та охорона праці осіб, зайнятих у догляді корів - 3 інструкції. (1. Підбір кадрів та проведення навчання. 2. Охорона праці та поводження 3 тваринами. 3. Проходження медичного огляду особами, зайнятими на фермі).

1.1.1. Підготовка корів до доїння - 2 інструкції (1. Підгін та запуск корів до доїльного залу. 2. Очищення дійок, здоювання перших цівок та заходи за виявлення маститу).

1.1.2. Належна процедура доїння - 1 інструкція. (1. Одягання/знімання доїльного апарату та контроль часу доїння).

1.1.3. Заходи після доїння - 1 інструкція (1. Застосування засобів для дезінфекції дійок після доїння).

2.2.1. Технічна справність молочного обладнання 3 інструкції (1. Перевірка цілісності корпусу доїльних апаратів та труб доїльного обладнання, міцності з'єднань. 2. Перевірка належної роботи бойлерів, насосів, вакууму, температури у молочному танку, надійності утримання фільтрів. 3. Оновлення деталей молочного обладнання).

2.2.2. Належний санітарно-гігієнічний стан молочного інвентарю, обладнання та мікроклімату молочного блоку -4 інструкції. (1. Проведення санітарних днів в молочному блоці. 2. Миття доїльного обладнання кислото-лужними засобами та прання індивідуальних серветок. 3. Приготування/використання кислото-лужних засобів. 4. Забезпечення належної вен- тиляції, освітлення та температурного режиму у доїльному залі).

2.2.3. Гігієна та охорона праці осіб, зайнятих у молочному блоці ферми - 2 інструкції. (1. Здоров'я та стан шкіри рук, осіб, зайнятих у молочному блоці. 2. Техніка безпеки під час роботи з молочним обладнанням та кислотно-лужними засобами).

Отже, сформований нами підхід до запровадження належної практики молочного фермерства в умовах вітчизняної молочної ферми 3 метою отримання безпечного та якісного молока-сировини має 12 процедур та 72 інструкції. Належна практика молочного фермерства розробляється для кожної ферми індивідуально i сформований нами підхід дозволяє об'єктивно підійти до аналізу виробництва та скласти інструкції відповідно до технічних можливостей ферми. При цьому інструкція повинна вміщувати такі пункти: мета, виконавці, основна частина, корекції, коригувальні дії. Інструкції не повинні бути занадто «наукові», обтяжені теоретичним матеріалом та великою кількістю неконкретизованих вимог, які важко довести до працівників. 3 часом програми належної практики молочного фермерства повинні пройти процеси валідації (підтвердження, яке має на меті створити документальні докази того, що певний процес на постійній основі відповідає заздалегідь визначеним цілям) та верифікації (перевірка шляхом обстеження та надання об'єктивних доказів дотримання визначених вимог). Внаслідок цього в умовах конкретної ферми може бути зменшена кількість інструкцій або розроблені нові.

Важливим елементом ефективного функціонування належної практики молочного фермерства та третьою складовою розробленого нами алгоритму є наявність на фермі прифермської лабораторії для контролю показників якості молока-сировини. Рекомендується, щоб тестування з метою оцінки якості молока щодо гігієнічних та фізико-хімічних показників проводилося для кожної партії молока. Окремі ферми, що використані для дослідження, не мають зазначених лабораторій, передовіряючи роботу 3 визначення якості молока-сировини лабораторіям молокозаводів. Це ускладнює оперативний щоденний контроль гігієнічного стану виробництва молока-сировини. У результаті знижується безпечність і окремі показники якості виробленого молока. Орієнтиром для встановлення належної практики молочного фермерства можуть слугувати розроблені науковцями методичні рекомендації та посібники (Guide To Good..., 2010; Iakubchak, 2010; Guide to good..., 2011), а також вказівки щодо належної практики молочного скотарства, видані під егідою FAO тощо. Розробити детальні процедури виробництва, які були б зручними та ефективними відразу для всіх ферм, неможливо.

Ферми, на яких не запроваджено належної практики молочного фермерства, не можуть бути проаналізовані щодо появи небезпек під час виробництва безпечного та якісного молока-сировини. Неможливість такого аналізу свідчить про відсутність гарантії безпечності виготовлених 3 цього молока-сировини молочних продуктів. 


\section{Висновки}

Розроблено алгоритм імплементації належної практики молочного фермерства на фермах України. Алгоритм складає створення робочої групи, розроблення 12-ти програм (які забезпечені 71-ю інструкцією) та встановлення прифермської лабораторії.

Розроблено два блоки програм забезпечення належної практики молочного фермерства. Перший блок програм забезпечення благополуччя корів включає 6 програм та 58 інструкцій. Другий блок програм отримання безпечного та якісного молока-сировини включає 6 програм та 13 інструкцій.

Перспективи подальших досліджень Доцільний аналіз результатів впровадження розробленого алгоритму в умовах молочних ферм України.

\section{Бібліографічні посилання}

Dykun, A. (2017). Technological revolution has been made, ahead - mental. Milk and farm, 1(38), 9-12 (in Ukrainian).
Nita, I. (2016). Protecting product quality and hygiene in milk processing. International Dairy Topics. 15(5), 11-13.

Dufour, S., Fréchette, A., Barkema, H.W., Mussell, A., Scholl, D.T. (2011). Invited review: Effect of udder health management practices on herd somatic cell count. J. Dairy Sci. 94, 563-579. doi:10.3168/jds.2010-3715

Tsikunova, O.G. (2016). Productivity of dairy cows under kept and milking technology. Materials of XIX Int. conf. «Actual problems of intensive livestock development» Gorki. 2, 340-344 (in Russian).

Guide To Good Farming Practices For Animal Production Food Safety (2010). Rome, FAO and OIE, 59.

Guide to good dairy farming practice (2011). Rome, FAO. 8, 50.

Iakubchak, O.M. (2010). Milk and dairy products (GMP/HACCP). Kyiv, Bioprom (in Ukrainian).

Received 4.09.2017 Received in revised form 29.09.2017 Accepted 3.10.2017 